Studies in African Linguistics

Volume 42, Number 1, 2013

\title{
THREE-PLACE PREDICATES IN WEST AFRICAN SERIALIZING LANGUAGES
}

\author{
Felix K. Ameka \\ Leiden University
}

\begin{abstract}
The widespread assumption that serializing languages use serial verb constructions (SVCs) to code three-participant situations and therefore lack three-place predicates and three-place mono-verbal constructions is shown not to be valid for West African serializing languages. Using Ewe (Gbe), Likpe (Na-Togo) and Akan (Tano) as exemplars, I demonstrate that these languages have trivalent predicates and various constructions in which a single verb hosts three arguments in a clause. The languages deploy three-place predicate, adpositional, SVC, and adnominal strategies to code three-participant situations. I argue that there are semantic differences between the various constructions. The hyper-transitivity of these languages might account for the presence of three-place predicate constructions.
\end{abstract}

\section{Introduction ${ }^{1}$}

A widespread assumption in the literature on serializing languages is the claim that such languages use serial verb constructions (SVC) to code three-participant situations. The corollary of this assumption is that such languages do not have structures in which a single verb hosts three overt surface arguments (see e.g. Nylander 1997, and Delplanque 1998 for some other myths about verb serialisation). These assumptions may be valid for some serializing languages but do not apply across the board to all serializing languages. Even for those languages where it seems to hold, I would argue that other typological features of those languages contribute to the property rather than serialization as such.

1 The ideas discussed here were first presented during the Dative Days at the Institut für Afrikanistik at the University of Cologne in June 2002. I am grateful to Erhard Voeltz who invited me and suggested the topic. I also thank the participants for their comments and animated discussions on grammaticalisation and transitivity. Sasha Aikhenvald also gave valuable comments on an initial draft. I am greatly indebted to Ron Schaefer for reviving its publication and to the anonymous referees for their comments and disagreements with some of my analyses. I hope I have satisfactorily responded to their skepticisms. I thank Tucker Childs for his patience and understanding. 
With respect to West African languages, such a claim has been made by Dimmendaal (2001). He writes:

Cross-linguistically, there are different types of serial verb constructions ... Periphrastic causatives (make/give/let $\mathrm{x}$ do $\mathrm{y}$ ), for example, are widespread crosslinguistically. The latter, however, are quite compatible with verbal valency-changing markers in a particular language, or with case marking strategies. In this sense they are not a predictor of a language type. A central feature of West African languages with serial verbs however is the lack of three-place predicates. Instead, a second verb (prepositional verb, coverb, verbid) is required to host a third argument (Dimmendaal 2001:384 emphasis added).

In the context of the distribution of serial verb constructions in West Africa, Dimmendaal argues that the languages that use them tend not to use verb derivational morphology for the coding of three-participant situations and suggests that serialization is the factor responsible for the paucity of three-place verbs, be they simple or derived. He notes:

Andy Pawley (p.c.) has suggested that the absence of three-place predicates in West African languages may be epiphenomenal. Whereas this observation no doubt is justified with respect to Papuan languages ... the situation in the case of the West African Niger-Congo languages must be different. Outside this spread zone for serial verbs, there is a widespread tendency to use verb morphology (Dimmendaal 2001:384-385).

My aim in this paper is to demonstrate that the assumptions relating to ditransitive verbs, three-place verb constructions, and verb serialization do not hold for West African serializing languages. I will show that these languages do have three-argument verbs of different kinds. They also have three-place constructions where a verb hosts three surface arguments. Furthermore, I will show that some verbs are ambivalent and can participate in different argument structure constructions in which case the construction licenses some of the arguments.

My illustrations are taken from three languages. I describe in detail three-place verbs and constructions in Ewe (Gbe), usually cited as a representative of a Kwa-type serialising language (cf. George 1975[1981]). ${ }^{2}$ I set out the types of predicates and constructions

2 The Ewe data are drawn from various sources: oral performances, folktales, and other verbal art genres and television and radio drama as well as written plays and fictional novels. Where the data come from the written sources, they are referred to in one of two ways: (i) if taken from the paper version, the author, year and page number are given. (ii) If cited from my electronic database of written Ewe, it is referenced with title of book with the concordance number in square brackets. 
involving three-participant situations in the language. I complement it with a look at the same phenomena in two other languages Akan (Tano) and Likpe (Sekpelé), a Na-Togo language. It is shown that the phenomena in the three languages are very similar. I argue that the use of three-place constructions for coding three-participant situations is favoured by the presence of obligatory complement verbs or inherent complement verbs (Avolonto 1995, Essegbey 1999) in these languages leading to their hyper-transitive nature. ${ }^{3}$ From this point of view, the claim that the apparent lack of three-argument verbs in West African serializing languages may be an epiphenomenon reduces to a situation where that property is not a phenomenon at all. Rather what needs explanation are the differences between the West African languages in terms of the types of double object constructions they employ and the differences in the conditions under which serial verb constructions and double object constructions may be the linguistic representations of similar three-participant situations. For instance, under what conditions is the transfer of an item to a recipient more felicitously represented in a double object construction rather than a serial verb construction? We will see below that in Akan, for example, this depends on the definiteness of the thing transferred, while in Ewe it depends on whether the transfer takes place between two co-present participants.

The variation in the expression of three-participant states of affairs in languages with serial verb constructions is an indication that one should not treat serializing languages as a homogenous linguistic type, nor is there a serialisation parameter (Newmeyer 2004, see also Baker 1989, Déchaine 1993). One can talk, though, of areal types such as a West African type, an Oceanic type, a Papuan type or a Southeast Asian type. There are serializing languages which lack three-place constructions. For instance, Enfield (2007) demonstrates that the assumptions about three-place constructions and verb serialization are by and large true for Lao, a Southwestern Tai language of Laos, Thailand, and Cambodia. He shows, however, that even though verb serialization is the "most common and most productive way of structurally accommodating reference to three event participants in a single clause in Lao" (Enfield 2007:521), other strategies consistent with the general typological profile of the language are also used, namely, topic-comment structures as well as the pervasive use of ellipsis in discourse. ${ }^{4}$ Furthermore, these typological features noted for Lao are typical for the

The Likpe (Sckpclé) data come from my corpus of Likpe language gathered during fieldwork visits to the Likpe area since the mid 1990s. I am grateful to my language consultants especially Mr. E. K. Okyerefo and Justina Owusu for helping me to understand their language.

The Akan data are taken from the Akan linguistic literature, especially Osam 1994, and cross checked with Akan native speakers.

3 Kropp Dakubu (2010:2) notes for Ga, another Kwa serializing language of West Africa, that a verb may be intransitive, transitive or ditransitive and adds that "by far the most common configuration is transitive ... most verbs that occur ditransitively can also occur with one object."

4 König and Heine (2007) report that !Xun, a Khoisan language of Namibia, has no ditransitive clauses but only monotransitive clauses, and SVCs participate in the expression of three-participant events. !Xun is thus another serializing language for which the assumptions seem to be valid. 
mainland Southeast Asia area (isolating, topic-prominent, verb-serializing, widespread nominal ellipsis) so that the strategies outlined for Lao presumably hold for several other languages in the area.

But there is variation among these languages in this domain too. While in Lao when threeparticipant situations are expressed in a monoverbal clause, non-theme arguments may be marked as peripheral adjuncts, Diller (2006: 161) notes for Thai, a Tai-Kadai language closely related to Lao, that "about twenty ditransitive verbs including hay ' ${ }^{2}$ give' admit AVOD (D being a dative-like indirect object)." Thus while it is tempting to say that the SE Asian type serializing languages conform to the widespread assumptions on the coding of threeparticipant events in such languages, one should be aware of possible variations among these languages.

Similarly, Margetts (2007) investigates the strategies used across the families of Oceaniaanother areal grouping of languages characterised by verb serialization (Crowley 2002, Bril \& Ozanne-Rivierre (eds.) 2004). She finds that Oceanic languages use clauses with three-place predicates occurring with three surface arguments less commonly than European languages. She adds that "there are a large number of Oceanic languages that have no ditransitive ... verbs at all." (Margetts 2007:124). Significantly, she attributes these features not to verb serialization but links them to another typological feature of these languages. She writes:

This tendency may be related to the typological characterization of Oceanic languages as preferred intransitive ... In preferred intransitive languages, the majority of basic verbs are intransitive, and most valency-changing processes are valency-increasing. If this is true, then deriving ditransitive verbs may require several steps and more morphosyntactic effort than in languages that are preferred transitive or neutral. So possibly the preference in Oceanic languages for strategies other than three-place predicates may be rooted, among other things, in their preferred intransitive set up. [p. 124]

Thus even though Oceanic languages are also serializing and many of them do not have ditransitive verbs, Margetts links this feature to the preference for intransitivity rather than serialization. I claim below that the presence of obligatory complement-taking verbs, including inherent complement verbs in the West African serializing languages, suggests that they have a preferred transitive set up which is not averse to ditransitive verbs and three-place constructions.

In fact the best piece of evidence, in my view, for the non-correlation between the use of three-place predicates or double object constructions and verb serialization seems to be provided by Creole languages. It appears that a large majority of Creole languages use double object constructions even those whose superstrates do not have double object constructions such as Papiamento or Haitian Creole. These languages have the Romance languages, Spanish and French respectively, as their superstrates. And Romance languages do not seem to have 
double object constructions. Fewer Creoles use serial verb constructions than use double object constructions. What is even more remarkable is that a Creole like Papiamento which has double object constructions and serial verb constructions does not have the type of SVC called serial dative constructions, that is an SVC in which the final verb is a three-place verb of the "give" type (see Bruyn et al. 1999). Thus there does not seem to be a correlation. This paper demonstrates that West African serializing languages are another set of languages which shows that serializing languages do have double object constructions and three-place verbs.

Before turning to the phenomenon of three-place predicates, I will discuss another widespread assumption about what some would call the typical three-argument verb: 'give'.

1.1 The tyranny of grammaticalization. Another widespread assumption is that the presumed typical three-place 'give' verb grammaticalizes into a dative preposition in the context of serial verb constructions in many serializing languages. This has happened in some of the West African serializing languages but by no means all. An implication that is further associated with this is that the grammaticalization leads to the loss of the lexical verb, thus spawning, if you like, the paucity of three-place verbs in these languages. Carol Lord has made such a claim with respect to Ewe. She writes the following about the form ná 'GIVE':

The data suggest that the Ewe verb ná may be entering its decline: it appears infrequently as a main verb, and when it does it appears to allow non-standard object ordering; in serial constructions, where it commonly functions as a Recipient/Benefactive marker, modern speakers no longer conjugate it (Lord 1993:41, italics added).

There are several things that are puzzling in this comment. First, is the claim that the form ná occurs infrequently as a main verb. This claim is not supported by any text counts of the author. I took a cursory look at a concordance page of an Ewe modern novel (Hlõbiabia 'Seeking revenge') for the bare form ná. Out of 42 lines, 9 of these are fully fledged threeplace uses of the verb. The rest are serial verb constructions and some are prepositional uses. I believe if I did a more systematic count of all the forms of ná including those in which the verb is marked for various mood and aspect categories, a more complicated picture, which would not support the claim of the decline in the use of ná as a main verb, would emerge. Second, as we shall see below, the verb ná is not the only verb that occurs in the construction that Lord describes as involving the non-standard ordering of objects (see section 2). I argue below that this is a distinct double object construction type in the language. This is just an indication that the data suggest something different from what the grammaticalization literature would like us to believe (cf. Ameka 2006a on some other untenable claims about grammaticalization in Ewe). 
1.2 The organisation and assumptions of the paper. The rest of the paper is structured as follows: First, I discuss the different types of three-place constructions in Ewe as representative of the Gbe languages. I show that there are at least three types of three-place constructions in the language and the verbs that occur in these structures do host three surface arguments in a clause. I also show that some transitive verbs can occur in some of these threeplace constructions showing their productivity. Next, other strategies for coding threeparticipant situations such as the serial verb constructions and the dative and allative prepositional constructions are described. Some verbs require these prepositional constructions obligatorily in their three-place function. This is followed by a summary of the structures used for coding three-participant situations in two other Kwa languages: Akan as a representative of the Tano group and Likpe (Sekpelé) as a representative of the Ghana-Togo Mountain languages group. The section on Ewe is more detailed than those of the other two languages. This is because Ewe is considered a prototypical verb serialising Kwa language. In addition, it has been claimed that verb serialisation in the GTM languages, and for that matter in Likpe, is contact-induced (Dimmendaal 2001). Ewe would have been the conduit for this transfer (Ameka 2006b). The Likpe data presented shows that even if it changed its profile to a serialising language this has not led to impoverishment in its ditransitive verbs or threeplace constructions.

Margetts and Austin (2007) provide a descriptive typology for the coding of threeparticipant situations. They identify seven major strategies with subtypes. The major strategies are exemplified as far as possible from English and the subtypes are omitted in the list below:

(i) Three-place predicate strategy: All three-participants are expressed as syntactic arguments of the verb.

John baked Mary a cake.

(ii) Oblique and adjunct strategies: The verb takes two arguments, a third participant is expressed as an oblique argument or an adjunct.

John baked a cake for Mary.

(iii) Serial verb strategy: Two (or more) verbs combine in a complex construction and share the three participants as arguments (or adjuncts) between them. See the examples provided from the serializing languages below.

(iv) Incorporation strategy: One participant is expressed by an incorporated nominal. The a. example shows the incorporation while the b. example is a manifestation of the direct strategy. E.g. Bininj Gun-wok (Non-Pama-Nyungan, Northern Australia) 
a. Gamak gan-bolk-bukka-n ge. good 2/1-country-show-NPST your

'It's good that you will show me your country.' (Evans 2003: 452)

b. Gamak gan-bukka-n gun-bolk ge. good 2/1-show-NPST class4-country your 'It's good that you will show me your country.' (Nick Evans p.c. 2003)

(v) Adnominal strategy: The verb takes two arguments, a third participant is expressed as an adnominal dependent of one of the arguments.

They stole his money.

(vi) Directional strategy: The verb takes two arguments and an adverbial directional marker indicating transactional orientation. E.g. Maori (Oceanic, New Zealand)

Naa te kurii $i$ mau mai te raakau.

ACTGEN the dog TAM bring hither the stick

'The dog brought me a stick.'

In this example, it is only the directional particle mai 'hither/towards the speaker' which codes the recipient.

(vii) Absorption strategy: There are two arguments in the clause but the verb includes information about a further participant. (Margetts and Austin 2007:402)

a. We shelved the books.

b. They bottled the wine.

I doubt if West African languages employ the incorporation or directional strategies. Even though the adnominal and absorption strategies may be represented, ${ }^{5}$ we will be concerned primarily with the first two strategies with some remarks on the third.

5 In fact, the predicate meanings that Margetts and Austin discuss as cases of lexical absorption such as English 'kick', 'punch' and 'stab' in which the instruments such as foot, fist and knife are absorbed in the verb, are not available in many West African languages. For these languages, these instruments have to be explicitly expressed for the sentence to be grammatical. These instruments are inherent objects, and the patient or target is coded as second or Dative (Goal) objects. For instance, to express the idea of 'stab someone' Ewe uses the expression tó hẽ ame 'contact knife person'. Margetts and Austin's 


\section{Ewe (Gbe)}

The first of the languages to be discussed is Ewe, a Gbe (Kwa, Niger-Congo) language spoken in southeastern Ghana across to southern Togo and just across the Togo-Benin border. Ewe is a tone language, morphologically isolating with agglutinative features with constituent order marking grammatical relations. It has AVOD and SV order and syntax. It is an aspect prominent language and does not have grammatical tense.

The structure of a verb cluster is shown in Table 1, where a verb stem may be marked for aspect by a suffix and/or preceded by a host of other preverbs that signal aspect, modality and directionality (see Ameka 2008a). The irrealis markers in column 1-the potential and the subjunctive-are mutually exclusive with each other, and also with the Habitual marker in the final column. A value of the realis/irrealis domain has to be expressed in each verbal clause in Ewe.

Table 1: Ewe verb complex

\begin{tabular}{|l|l|l|l|l|l|l|l|}
\hline \multicolumn{2}{|l|}{ Preverb markers } & Directional 1 & Modal 2 & Modal 3 & Directional 2 & & Aspect Suffix \\
\hline Modal 1 & Aspect & Rerb \\
\hline $\begin{array}{l}\text { Potential } \\
(1) a\end{array}$ & $\begin{array}{l}\text { Ra } \\
\text { gatitive }\end{array}$ & $\begin{array}{l}\text { Itive } \\
\text { hé }\end{array}$ & $\begin{array}{l}\text { Certainty } \\
\text { nyá }\end{array}$ & $\begin{array}{l}\text { Immediate } \\
\text { gbé }\end{array}$ & $\begin{array}{l}\text { Ventive } \\
\text { vá }\end{array}$ & $\begin{array}{l}\text { Verb } \\
\text { root }\end{array}$ & $\begin{array}{l}\text { Aorist } \\
\varnothing\end{array}$ \\
\hline $\begin{array}{l}\text { Subjunctive } \\
\text { ná- }\end{array}$ & & $\begin{array}{l}\text { Altrilocal } \\
\text { da }\end{array}$ & $\begin{array}{l}\text { Voice } \\
\text { nyá }\end{array}$ & $\begin{array}{l}\text { Bother } \\
\text { xa }\end{array}$ & & & $\begin{array}{l}\text { Habitual } \\
\text { (n)a }\end{array}$ \\
\hline
\end{tabular}

About one third of the verb roots in the lexicon are intransitive. Almost all of these are ambitransitive. When most of these verbs occur in transitive structures, the $\mathrm{S}$ argument can either surface as A or O. For only a handful, for example dze 'land', is the S argument realized as A. A majority of Ewe verbs take obligatory complements. The complement functions as a direct argument of the verb. In addition, there are several types of ditransitive or trivalent verbs, as we shall see below. Virtually all verbs participate in multiple argument realization, some of them involving event composition, i.e., having semantic implication, while others reflect a difference in perspective-taking (Levin and Rappaport-Hovav 2005; and see e.g. Ameka 2008b, Bobuafor 2001, Bobuafor et al. 2006/7, Essegbey 1999 for discussions of Ewe verbal alternations). 
For Ewe, one can identify three distinct grammatical constructions, by which I mean formmeaning pairings with sub-constructions in some cases, which are used to characterize threeparticipant situations. We will label these the THEME-GOAL Double Object Construction; the GOAL-THEME Double Object Construction and the Object Complement Construction. In these constructions, three surface NP constituents function as direct arguments of a single predicate. There are two distinct constructions in which the third argument in a three-place construction is coded as an oblique. These are labeled after the prepositional head of such constituents as the DATIVE OBLIQUE three-place construction and the ALLATIVE OBLIQUE three-place construction. Each of these will be described in turn.

2.1 The THEME-GOAL three-place construction. This construction, whose semantics can be characterized, following Essegbey (1999), as 'caused transfer' has the following structure:

\section{$\operatorname{Actor}(=\mathrm{X})$ - V -THEME $(=\mathrm{Y})-\operatorname{GOAL}(=\mathrm{Z})$}

Essegbey (1999:170) argues that "there are three specific ways in which the transfer is encoded and each instantiation is dependent on the semantics of the particular verbs. The three senses are represented below:

a. $\mathrm{X}$ causes $\mathrm{Y}$ to undergo a change of location towards $\mathrm{Z}$

b. $X$ causes $Y$ to make contact with $Z$

c. X causes $Y$ to be located at $Z$ "'

There are various classes of verbs that enter this construction. The first are the typical three core participant verbs such as ná 'give' tsyé 'give a gift', fiá 'teach/show' bíá 'ask', dó 'send (someone) for something'.

\section{(1) Kofí fiá agble-a deví-á-wó \\ NAME show farm-DEF child-DEF-PL \\ 'Kofi showed the farm (to) the children'}

For this sub-construction, the THEME argument is not an inherent complement of the verb. Some of the verbs that participate in it can, however, take inherent complements such as the collocations fiá así [show hand] 'point to' or dó dž [send work] 'send on an errand'. These require a second object to be used felicitously, showing that these verbs are primarily trivalent. Even though these complements are described as inherent, it does not mean that they do not represent independent participants in the situation. Moreover, it has been demonstrated by e.g. Essegbey 1999, 2010 and Ameka 2008b, that these inherent complements are direct arguments of the verb. 
Similarly, a second group of verbs that occur in the THEME-GOAL three-place construction are those that have an inherent complement filling the THEME slot (see Essegbey 2003, 2010). The verbs in this group have the generic entity nominal nú 'thing' as the inherent object. These verb phrases are of two kinds: those like xlı̃ nú $\mathbf{Z}$ 'advise $Z$ ' where the nú 'thing' cannot be substituted for by anything else (although it can be modified) and others like te nú $\mathbf{Z}$ 'deny something to $Z$ ' where the thing can be made specific, as in (2).

Dadá-á te núdudu-i
mother-DEF drag food-3SG
'The mother denied her/him food.'

These verbs require a third argument to be expressed for them to be used felicitously in a clause.

A third sub-construction of the THEME-GOAL family of constructions is one in which the THEME is an inherent complement and it is a body part. In the instantiations of this construction the THEME body part is construed as part of the Actor argument. They may be interpreted as the Actors causing a part of their body to make contact with another entity. Depending on the semantics of the verb (phrase), the instantiation may be interpreted as experiential as in (3a) in which case the GOAL argument is construed as an experiencer (Ameka 1990, 2002a). In (3b-3f) I list several verb phrases with generic nouns as place holders to illustrate the ubiquity of expressions that belong to this sub-constriction.

a. deví mamlea-á-wó á-va yu-i
child rest-DEF-PL POT-move EYE-3SG

'The other children would be jealous of him/her.'

b. dó Đkú náné dzí set eye something surface

'remember something'

c. ká fe ame

break.off nail person

'pinch someone to give info'

d. mia así ame signal hand person 'beckon someone' 

e. tó así náné dzí
contacth and something surface
'identify/select something'
f. tu kó ame
ram fist person
'punch someone'

Another sub-construction of the THEME-GOAL three-place construction is used to express causative situations in which the GOAL argument is a causee. These typically involve the verb dó 'PUT, CAUSE'

a. srõ-a dó mó-e

spouse-DEF PUT road-3SG

'Her husband dispatched her.'

i.e. gave her the necessary authority and supplies to go

b. é-dó du só-á

3SG-PUT race horse-DEF

'He set the horse to run.'

Some predicates with causative motion readings can participate in the THEME-GOAL construction. These predicates include da 'THROW, release a projectile' and fú 'move limbs in medium'. Instantiations of this sub-construction indicate that an Actor causes a THEME to come in contact with a GOAL which could be interpreted as a location, as illustrated in (5).
a. Kofí da bólu-o Yawo
NAME discharge ball-DEF NAME
'Kofi threw a ball at Yawo.'

b. Kofí fú así nǔ hand move.limb hand mouth

'Kofí hit his hand against his mouth.'/ 'Kofi raised an alarm.'

A final sub-construction of the THEME - GOAL double object construction is one in which the predicate wo 'do, make, cause' functions as the verb. Consider the following examples. 
(6)
a. tsi.dza.dza wo nú-m ló
rain do thing-1SG UFP

'The rain did something (=something bad) to me.'

b. é-wo náné noví-á 3SG-do something sibling-DEF

'She did something (=something bad) to her sibling.'

The GOAL argument in such constructions is construed as being negatively affected by the event directed at them. For a benefactive reading to be realized with this predicate the GOAL argument has to be coded as a Dative Prepositional object as we shall see below.

2.2 The GOAL-THEME three-place construction. The prototypical trivalent verbs, namely, ná 'give' tsyé 'give a gift', fíá 'teach/show' bíá 'ask', dó 'send (someone) for something' occur in this construction where the iconic order of an Actor transfers a Theme to a Goal participant is reversed. In this structure the GOAL precedes the THEME, as shown in (7). Compare (7) with (1) above.

$$
\begin{aligned}
& \text { Kofí fiá deví-á-wó agble-a } \\
& \text { NAME show child-DEF-PL farm-DEF } \\
& \text { 'Kofi showed the children the farm.' }
\end{aligned}
$$

Interestingly, the GOAL-THEME construction is a marked structure in Ewe and other Gbe lects. It involves a gestalt reversal. However, this is the basic construction for double object constructions in other Kwa languages including Akan (see below) and several Ghana-TogoMountain Languages such as Likpe (see below), Logba (Dorvlo 2008) Tafi (Bobuafor 2013) and Nyagbo.

2.3 Three-place object complement constructions. These are constructions in which there are two post-verbal NPs with one of them optionally flagged as secondary predicate, marked by the Predication marker -i, written as ' $e$ ' in the examples (see Ameka and Schultze-Berndt 2000, Ameka 2005a). Object complements of two classes of verbs occur as second postverbal NPs.

The first set are certain factive verbs that take 'object complements', e.g. wo 'do, make', dó 'set', kpa 'carve', gbi ‘weave', tiá 'elect', நlo ‘write' (cf. Amuzu 1993: 61-72).

$$
\begin{aligned}
& \text { a. du-a dó Kofí fia-e } \\
& \text { town-DEF install NAME chief-PRED } \\
& \text { 'The town installed Kofi as chief.' (Amuzu 1993: 62) }
\end{aligned}
$$


b. wó-nlo wó nya deká-e

3PL-write 3PL word one-PRED

'They write them as one word.' (Collins 1993: 24, cited from an orthography manual)

The second set of predicates are verbs of perception and cognition which also take 'object complements', e.g. kpó ‘see', bu 'think' (cf. Amuzu 1993: 61-72).

$\begin{array}{llll}\text { Áma } & \text { kpó } & \text { srõ-a } & \text { ga-tó-e } \\ \text { Name } & \text { see } & \text { spouse-DEF } & \text { money-owner-PRED }\end{array}$

'Ama saw her husband as a rich person.' (Amuzu 1993: 61)

... gaké míé-bu wó nánéké-e o but 1PL:NEG-think3PL nothing-PRED NEG

'.. but we did not think them anything (i.e. we did not think anything of them)' (Ayeke 1996: 82)

Margetts and Austin (2007) exclude such object complement structures from their typological survey because the three surface constituents do not represent distinct entities. I include them here, first, because the object complement behaves in all respects like a direct argument, for instance with respect to extraction for focus. A second reason is because on the surface the three constituents appear with some of the predicates that occur in other threeplace constructions, e.g. the factive verbs. In fact, Margetts and Austin admit that such structures may be ditransitive. In the next two sections we look at three-participant constructions in which one of the participants is coded as an oblique or a prepositional object. Two prepositions are typically used in Ewe for this: the Dative ná and the Allative dé.

2.4 DATIVE OBLIQUE three-place constructions. For various three-participant situations, one of the participants is coded as the object of the dative preposition ná. This is the case with the coding of addressees of routines (11), in speech act verb constructions (12) and in delocutive constructions with the verb dó 'PUT, cause, say' as in (13).

(11) me-dá akpé ná wò

1SG-PUT thanks DAT 2SG

'I thank you.'

(12) Dziqudu de adzogbe ná Agbeko bé ... government remove destiny DAT NAME QT 'The government has sworn to Agbeko that ...' (Hõbiabia [18]) 
(13) Míá-fé Fia-gấ Agokólí ... dó gbe ná mi. 1PL-POSS chief-big NAME PUT voice DAT 2PL

'Our supreme chief Agokoli ... greets you.' (Kwamuar1997: 15)

Similarly, Experiencers in experiential situations involving three participants where the Stimulus functions as the grammatical subject are also coded as dative prepositional objects, as shown in (14) (cf. Ameka 1990).
a. nya lá kú dzi nê word DEF die heart DAT:3SG

'The matter angered him/her.'

b. é-fá akó ná-m

3SG-cool bosom DAT-1SG

'She comforted me.'

The subjective evaluator or experiencer in evaluative and emotive modal constructions involving three-participants is also coded as a dative prepositional object. In these structures one of the participants is a situational participant realized as an impersonal pronominal subject in the matrix clause. The content of the situational participant may be spelled out in a complement clause (Ameka 2008a). For example:

$\begin{array}{llllllll}\text { é-dzo } & \text { dzi } & \text { ná-m } & \text { bé nye } & \text { mâ-gblế } & \text { wò } & \text { dí } & \text { o } \\ \text { 3SG-straighten heart } & \text { DAT-1SG } & \text { QT 1SG } & \text { NEG:POT-spoil } & \text { 2SG } & \text { down } & \text { NEG }\end{array}$

'It pleases me that I will not leave you behind.'

Furthermore, the affected possessor in external possessive constructions, which also constitute three-participant situations, is also coded as a dative prepositional object (cf. Ameka 1996).

(16) Kofi yé afon n̂े

NAME break leg DAT:3SG

'Kofi broke his (someone else's) leg.' lit: Kofi broke leg to him.

$\begin{array}{lll}\text { srõ-a } & \text { fo tó.me } & n \hat{\varepsilon} \\ \text { spouse-DEF } & \text { hit ear.containing.region } & \text { DAT:3SG }\end{array}$

'His spouse slapped him' lit: 'His spouse hit ear region for him.'

This construction is also used to introduce dative arguments more generally such as recipients, e.g 18 a., b., beneficiaries as well as maleficiaries, e.g. $18 \mathrm{c}$. 
(18) a. é-nlo agbalẽ ná é-dzilá-wó 3SG-write letter DAT 3SG-parent-PL

'He wrote a letter to his parents.'

b. núfiáládó do ná sukuví-á-wó teacher set work DAT pupil-DEF-PL

'The teacher set work for the pupils.'

c. kpovító-wó dó fe na dráiva lá police-PL put debt DAT driver DEF 'The police heaped a debt on to the driver.'

As is evident from the examples, many of the situations for which a third participant is required and coded through a dative oblique construction in Ewe would normally surface with two participants in a language like English. In this sense Ewe has many more situations presented as involving three participants which surface as three arguments in a clause even if one is oblique.

2.5 ALLATIVE OBLIQUE three-place constructions. The allative oblique construction is used to code the GOAL as an indirect argument of some three-participant situations. This construction can be used to characterise a transfer event involving a targeted recipient coded as the allative complement where the implication is that it is not known whether the GOAL argument came to have the transferred entity, as illustrated in (19).

é-dó agbalẽ dé é-dzilá-wó

3SG-set letter ALL 3SG-parent-PL

'S/he sent a letter to his/her parents.'

The endpoint target of a movement or a caused motion event is also coded as an oblique allative object, as in (20).
a. é-da avo dé abo
3SG-throw cloth ALL arm

'He has draped cloth over his shoulder.'

b. deví-á da ga-a dé kplõ-a dzí child-DEF throw money-DEF ALL table-DEF upper surface 'The child put the money on the table.' 
Addressees of speech acts that are negatively affected are also coded as objects of the allative preposition.
é-dó ylí dé deví-á-wó dzí
3SG-say shout ALL child-DEF-PL upper surface
'He shouted at the children.'

2.6 Serial verb constructions with three-place verbs in final verb position. Most of the three-participant situations characterised by the various three-place constructions described so far can be paraphrased as serial verb constructions. SVCs are thus just one of the many options in the language for coding three participants in a single clause in Ewe (see Collins 1997, Ameka 2006c and references therein on Ewe SVCs). When three-place predicates occur in SVCs they typically occupy the final verb position in such clauses, and their direct objects are the semantic dative or GOAL participants, but they share the other arguments of the other $\operatorname{verb}(\mathrm{s})$ in the series. Consider the following sentences.
a. é-de deví lá fiá ame-wó
3SG-remove child DEF show person-PL
'S/he introduced the child to the people.'
b. wó-mé-tsó-á belélé ádéké hã ná-á núkú-á-wó o 3PL-NEG-take-HAB care INDEF also give-HAB crop-DEF-PL NEG
'They do not also give any care to the crops.' (Hlõbiabia 3116)
c. é-tu así-i fú anyí
3SG-hit hand-3SG move.limb ground
'S/he shoved him/her to the ground.'
d. é-nlo agbalẽ dó dé é-edzilá-wó 3SG-write letter place ALL 3SG-parent-PL 'S/he wrote a letter to the parents.'

There are different motivations for coding three-participant situations in an SVC than, say, in a double object construction. This may be semantic. For instance, the SVC in (22a) is the only way to express the idea of 'introducing someone to someone else'. If the verb fiá 'show' is used in a comparable double object construction it only entails that the people (the dative participant) could see the person (but may not know anything more about the person). The SVC implies that the dative participant gets some more information about the person. Also an 'A-take-X-give- $\mathrm{Y}$ ' SVC entails that A and $\mathrm{Y}$ are co-present when the transfer takes place. 
However, for a double object construction with 'give' the Agent and Goal participants need not be in contact.

In the rest of the paper we look briefly at two other languages-Likpe and Akan-which are also serializing and yet have three-place predicates which surface with three arguments in a single clause.

\section{Likpe (SEkpelé)}

Likpe (autonym Sekpelé) is a Na-Togo, Kwa, language. It is head-marking at the clause level as well as a serializing language and has several predicates which surface with three arguments in a clause. The verbs in a Likpe serial verb construction (SVC) must share the same Subject. The Subject is expressed on subsequent verbs by a Subject pronominal concord. In addition, Sekpelé has retained a number of verb derivational suffixes. These include the productive causative -sá and the associative -ko and a semi-productive "contactive" extension -fá. Each of these can be used to introduce a core third argument into an otherwise transitive clause (Ameka 2009b).

There are three double complement constructions. In one type of double object construction in the semantic frame of TRANSFER the DATIVE or GOAL argument precedes the THEME. In another type the THEME precedes the LOCATIVE. This LOCATIVE is used for PLACEMENT events. While the order of the TRANSFER construction is fixed, in the PLACEMENT construction the Figure (THEME) Ground (LOCATIVE) alignment can be reversed where the LOCATIVE precedes the THEME. A third structure with two complements is one in which the second complement is a situational argument, and is typically coded as a nominalized verb. This structure is used to characterize various circumstantial aspects of states of affairs such as modality, attitudinal meanings and aspect (see Ameka 2009a for more details on participant coding).

3.1 The GOAL THEME or Dative Double Object Construction. In this construction, the Dative or GOAL argument occurs in the immediate post-verbal position while the THEME argument occurs after it. This order of the Dative and the Theme arguments is fixed and cannot be reversed. Roughly speaking, the message of such a construction is (caused) transfer:

Someone (Actor) does something (Verb) to something else (THEME)

Because this person (Actor) wants someone else (GOAL) to have this thing (THEME)

Several verbs participate in this construction: the prototypical transfer verbs such as tó 'give' or té 'show, teach, sell' used to describe three-participant events are found in this construction. 
(23)

a. mo anto ə-tá li-kpéfí nó-má a-taabí

1SG father SCR-give CM-child AGR-DET CM.PL-cowry

'My father gave the child money.'

b. fo tó me si-kpi

2SG give 1SG CM-fear

'You frighten me.'

Handling verbs such as the verb tá 'handle an instrument with a long dimension to do something to something else', glossed as 'shoot, kick, sling' also occurs in this three-place construction as illustrated in (24).

Sáka à-tà u-kiti ko-tá

Name SCR-shoot CM-wolf CM-gun

'Saka shot (the gun) the wolf.'

Furthermore, a verb like di 'eat, experience' can be used in the dative double object construction to describe a speaking event. The 'eating' verb then surfaces with minimally three arguments. Consider the following example.

$\begin{array}{lllllll}\text { o-sani } & \text { á-má } & \text { ว-dí } & \text { wə } & \text { u-síá } & \text { li-tikí } & \text { mínímíní } \\ \text { CM-man } & \text { AGR-DEF } & \text { SCR-eat } & \text { 3SG } & \text { CM-wife } & \text { CM-word } & \text { sweet }\end{array}$

'The man said something sweet to his wife.'

Some contact verbs such as so 'strike' also participate in the dative double object construction. Another such verb is sé 'be.contacted' which can be used in a three-place construction to describe a stabbing event where it is presented as an Actor moves a theme (instrument), e.g. a knife, and makes contact with a dative Object, see (26).
li-kpéfí ná-má a-sé
wo 0-xว̃́ le-síábí
CM-child AGR-DEF SCR-be.contacted 3SG CM-friend CM-knife
'The child stabbed his friend.'

The 'do' verb in Likpe yifó 'do', like its counterpart in Ewe and Akan, can surface with three arguments in a mono-verbal clause as in (27).

$$
\begin{array}{lll}
\text { u-yifo me } & \text { u-tídi } \quad \text { yí-yí } \\
\text { 3SG-do 1SG } & \text { CM-person RED-know }
\end{array}
$$

'He is a known person to me.' 
A causativised verb such as yi-sá 'full-CAUS' also surfaces with three arguments in a clause as shown in (28).

(28) yi-sá me tánki

full-CAUS $1 \mathrm{SG}$ tank

'Fill the tank for me.'

It is important to note that each of the instantiations of the construction can be expressed in alternative constructions such as SVCs and even adnominal constructions where the verb may surface with two arguments and the third participant coded as a dependent of one of them. Thus an alternative way of expressing (28) is (29) which is a two-place construction in which the direct object argument is a possessive phrase representing two arguments (hence not a three place construction) but three participants, hence a three-participant expression.

\section{(29) yi-sá mo tánki \\ full-CAUS $1 \mathrm{SG}$ tank \\ 'Fill my tank'}

The difference between the structures described in this section and the next is in the semantic role of the GOAL argument. In the construction described in the next section it is a Locative while in previously discussed constructions it has been a Dative. Another difference between the two constructions is that the THEME-LOCATIVE construction has an alternative construction involving Figure-Ground reversal.

3.2 The THEME-LOCATIVE Double Object construction. This construction is used in the description of three-participant situations involving change of location or placement of entities. Locative verbs used to express caused change of location such as kpé 'be.in', tóká 'be.on', tó 'throw' and bóko 'bring' (from bá 'come' -ko 'ASOOC') participate in this construction. Examples of two of these verbs in this construction are given in (30).

a. o-fu Kodzó ó-má le-bokó a-sóle kú sikuu ka-kpelé-só Name Name AGR-DEF DEP-bring CM-church LINK school CM-Likpe-land 'Ofu Kodzo brought church and school to Likpe land.'

b. u-tókó ko-fâ le-fabé 3SG-be.on CM-medicine CM-wound 'He put medicine on the wound/sore.' 
A sub-construction of this structure is that the order of the Theme and the Locative Objects can be reversed yielding a different gestalt relation between Figure and Ground. Thus a variant of (30b) with LOCATIVE-THEME order is shown in (31).

$$
\begin{array}{ll}
\text { u-táká le-fabé ko-fâ } \\
\text { 3SG-be.on } & \text { CM-wound CM-medicine }
\end{array}
$$

'He put medicine on the wound/sore.'

3.3 The Double Complement Construction. In this construction one of the post-verbal constituents is formally a nominalised verb. Verbs can be nominalised in Likpe, and gerund forms are derived by prefixing the class marker $\mathbf{b V}$ - to verb roots. ${ }^{6}$ Such forms behave like any other nouns and can fill argument positions in a clause. Where the nominalisation involves a verb and its internal argument the $[\mathrm{V}-\mathrm{NP}]$ order is permuted. The verbs that participate in this construction include verbs of wanting such as la 'want', ni 'refuse' and operator verbs in constructions involving the modelling of states of affairs with respect to aspect or modality such as lé 'hold' in the present progressive construction (see Ameka 2002b) or fo 'can' in the ability modal construction.

This construction is also used to code three-participant situations; the main or operator verb has two complements the second of which is a nominalised verb. There is a close relationship between the two complements in the sense that the immediate post verbal complement tends to be an internal argument of the nominalised verb constituent. In terms of roles, the first complement is like a GOAL more broadly construed and the second complement is a Theme. A reviewer challenges the claim that such structures involve three participants especially given the close relationship between the nominalised verb complement and its internal argument. First of all, the nominalised verb complement behaves in all senses as an event nominal. It can be extracted for, for example, focus independently of its internal argument. Moreover, the relationship that exists between the two complements is parallel to the structural relation that has been proposed to exist between bona fide double objects in Xbar treatments, see e.g. Hellan 1988. I maintain that these structures are clauses in which a verb surfaces with three NPs which can be considered as semantic participants.

$$
\begin{aligned}
& \text { a. li-kpéfí nó-mó a-ni le-sa bú-di } \\
& \text { CM-child AGR-DEF SCR-refuse CM-thing } \\
& \text { 'The child refused to eat the food' }
\end{aligned}
$$


b. moo-fo fo bó-so né ló 1SG:POT-can 2SG CM-hit INFER UFP

'I can hit you, you know' [A mother threatening a child]

Even if one does not want to accept that on the surface there are three syntactic participants represented, one would have to concede that there are three semantic participants and maybe two of those are coded in a way similar to the adpositional strategy as discussed and exemplified above. Example (29) above is an illustration of this for Likpe.

The three constructions described so far are structures in which all three participants in a situation are coded as direct arguments of the verb. In the next section we look at a construction in which a third participant, a locative argument, is coded as an oblique object of the locative preposition lá 'LOC.

3.4 LOCATIVE Oblique constructions. An alternative structure to the Double Object THEME-LOCATIVE construction is one in which the participant that has the Locative role fills an oblique function and is marked by the locative preposition lá 'LOC'. Some change of location verbs such as kpó 'be.heaped' and tsyí 'carry' occur in this structure.

$$
\begin{array}{llll}
\text { ú-tsyi } & \text { bi-kə } & \text { lá } & \text { di-sí } \\
\text { 3SG-carry } & \text { CM-load } & \text { LOC } & \text { CM-head }
\end{array}
$$

'He carried luggage on his head.'

In the description of three-participant situations involving removal, lending, borrowing, renting, stealing etc. the locative source participant is coded as an oblique locative argument marked by the locative preposition. For example:

o-teasá a-hayí dí-yó lá Sáka e.flo

CM-teacherSCR-rent CM-room LOC NAME place

'The teacher rented a room from Saka.'

Similarly, the representation of speaking events can involve three participants and in this case the TOPIC participant, that is, the constituent that represents the entity talked about, is coded as an oblique locative argument as in (35).

$\begin{array}{lllllll}\text { wəə-dí } & \text { ə-tikí } & \text { kpe } & \text { lá } & \text { li-kpéfí } & \text { nó-má } & \text { əsúá } \\ \text { 3SG:HAB-eat } & \text { CM.PL-word } & \text { plenty } & \text { LOC } & \text { CM-child } & \text { AGR-DEF surface }\end{array}$

'S/He says a lot of things (words) about that child.' 
External possessor constructions with bivalent predicates surface with three arguments in a clause. The third argument, the possessee, in such constructions is marked by the locative preposition as shown in (36).

(36) le-kpakpa kpé wə lá li-sí
CM-hat be.in 3SG LOC CM-head
Lit. 'A hat is on him at head.'

Thus far we have presented monoverbal constructions in which three arguments surface with a verb in a clause. In three of the constructions all three arguments are direct arguments of the verb, while in one case the third argument is an oblique. In the next section we show that Likpe also uses serial verb constructions (SVCs) to code situations involving three participants. In these structures, as is usual in serializing languages if one of the verbs involved is a three-place verb it occurs in the last verb slot in the construction.

3.5 Serial verb constructions. Serial verb constructions of different types also host three arguments in a clause. Situations involving three participants such as caused location, handling (see 37) and transfer (38 a., b.) can be expressed in SVCs. Such situations, as we have seen, can also be coded in monoverbal structures.

$\begin{array}{lllll}\text { ú-fi } & \text { o-fia } & \text { ó-má } & \text { o-k(e)lé } & \text { lí-si } \\ \text { 3SG-take } & \text { CM-headkerchief } & \text { AGR-DEF } & \text { 3SG-tie } & \text { CM-head }\end{array}$

'She used a headkerchief to tie (around) (her) head.'
a. u-síó
á-mó
á-ba a-taabí
u-tó wo
CM-woman AGR-DEF
SCR-loan CM.PL-cowry
3SG-give $3 \mathrm{SG}$
u-só
CM-husband
'The woman loaned money to her husband.'
b. moo-ya ka-mó n-tá be-kpéfí bá-mó
1SG:POT-buy CM-rice 1SG-give CM.PL-child AGR-DEF
'I will buy rice for the children.'

Thus, Likpe, a clause level head-marking language with verb derivational affixes, makes use of three sub-constructions of three-place predicate constructions, predicates with oblique arguments and SVCs for coding three-participant situations. SVCs are but one option. In the next section a similar picture emerges for Akan which is not head-marking and does not have verb derivational affixes. 


\section{Akan}

Akan belongs to the Tano subgroup of Kwa languages. Grammatical relations are predominantly determined by constituent order. It has SV and AVO order in intransitive and transitive clauses respectively. Inanimate pronominal objects are null. It has inherent complement verbs and deploys serial verb constructions. In ditransitive clauses it has a strict GOAL-THEME order for objects. As Osam (1996:62) puts it: "All ditransitive verbs in the language allow indefinite Theme NPs, but very few of them permit a definite Theme NP." Because of these features, three sub-constructions of the three-place predicate constructions can be identified: one in which the THEME argument must be indefinite, another in which the THEME can be definite or indefinite and a third in which the THEME is an inherent complement of the verb (see Stewart 1963, Osam 1997, Saah and Eze 1997 on double object constructions in Akan).

4.1 Three-place constructions. Akan, like Likpe, also has only one order for the objects in a three-place construction: GOAL-THEME. At least three classes of verbs participate in this construction. The first group are the prototypical ditransitive verbs of transfer or change of location verbs such as ma 'give away' kye 'give', bre 'bring' mane 'send' fem 'lend'. The main restriction with respect to these verbs and the three-place construction in which they occur is that the THEME cannot be definite nor pronominalized. Examples (39a) and (39b) are instantiations of this construction with the verb ma 'give away'. In the former the THEME argument siká 'money' is bare and is interpreted as indefinite. In (39b) the THEME argument is marked by the indefiniteness marker bí 'some'. The sentence in (39c) is ungrammatical because the THEME argument is marked for definiteness. An SVC can be used to express such a state of affairs grammatically (see section 5.3).

$$
\begin{aligned}
& \text { a. Kofí ma-a Áma siká } \\
& \text { NAME give-PAST NAME money } \\
& \text { 'Kofi gave Ama money.' } \\
& \text { b. Kofí ma-a Áma siká bí } \\
& \text { NAME give-PAST NAME money some } \\
& \text { 'Kofi gave Ama some money.' } \\
& \text { c. } \text { *Kofí ma-a Áma siká no } \\
& \text { NAME give-PAST NAME money DEF }
\end{aligned}
$$

A second set of trivalent verbs, mostly speech act or change of state verbs, also participate in a sub-construction of the three-place predicate construction with GOAL-THEME order. There is no definiteness restriction on objects in this sub-construction. The members of this 
class include bisa 'ask' kyere 'show/teach' sre 'beg/request' gye 'receive' (cf. Osam 1997). Consider the following examples:

a. Kofí kyere- $\varepsilon$ mbofra no ndwom

NAME teach-PAST children DEF song

'Kofi taught the children a song.'

b. Kofí kyere- $\varepsilon$ mbofra no ndwom no

NAME teach-PAST children DEF song DEF

'Kofi taught the children the song.'

A third group of verbs which can surface with three direct arguments in a mono-verbal clause are those that take inherent complements and obligatorily require a second object. The second object is a GOAL argument and occurs in immediate post-verbal position. The inherent complement is a THEME argument and occurs after the GOAL, as should be expected. As the inherent complement and the verb tend to be seen as belonging together and the GOAL argument as it were occurs between them, Osam (1994) talks of them as having developed into discontinuous verbs. Essegbey $(2003,2010)$, however argues that they are not discontinuous, rather the structures just conform to the order of elements in an Akan double object construction. Examples of such expressions include: ka $\mathbf{X}$ yaw 'tease $X$ ' bo $\mathbf{X}$ bosa 'give a loan to X' yi $\mathbf{X}$ aye 'praise X'. Sentences in (41) illustrate some of these. NAME V-PAST God IC 'Kofi praised God.'
a. Kofi yi-i Nyame aye
b. me-bo wo abaso $s \varepsilon \ldots$ 1SG-hit 2SG ?? COMP 'I congratulate you ...'

Some bivalent verbs also participate in three-place constructions and express specific (cultural) events. A case in point is twa 'cut' as used in example (42).
(42) me-twa wo asu firi kurom ha 1SG-cut 2SG river from town here 'I banish you from this town.'

In this example, twa 'cut' takes two objects and also an oblique locative argument marked by firi 'from'. I assume that this form is a grammaticalized form of the verb firi 'come from'. 
4.2 Three-place object complement constructions. Akan also makes use of constructions in which one of the objects is a complement of the other. In fact, in the example in (43), as a consequence of the verb being a three-place predicate, and one of the objects taking an object complement, the verb surfaces with four arguments.

(43) me-to wo din $\quad$ Kofi
1SG-throw 2SG name
'I name you Kofi.'

As indicated in section 2.3, Margetts and Austin (2007) do not consider objectcomplement constructions as distinct participants. However, as I argued there, such structures in the Kwa languages behave just like other three-participant constructions and hence they are included here.

4.3 Serial verb constructions. Akan, like the other languages discussed in this paper, has serial verb constructions. Christaller (1875) identifies two types which he labeled "essential combinations" and "accidental combinations". This classification has survived in Akan linguistics but they have been relabeled by Osam (e.g. 2004) as "Integrated SVCs (ISVC)" and "Clause Chaining"7 respectively. Osam (2004: 34-35) distinguishes the two types on the basis of semantic integration of subordinate events that are construed as representing a single event. Thus ISVCs represent "tightly integrated events"; benefactive SVCs such as those denoting "a praying for someone" event are an example. The so called "Clause Chaining" type are those in which the "verbs in the chain constitute the concatenation of otherwise potentially independent events" (Osam 2004: 34). For example, an SVC used to represent the scene of 'X got money built a house sold it'. Verbs in Akan SVCs share the same subject and are marked only once in the clause ${ }^{8}$ for tense and mood. If it is negative, each verb is marked for negation. Verbs in the series have compatible aspectual semantics.

A distinguishing feature of Akan in terms of the coding of three-participant situations is the definiteness restriction on THEMEs, as noted above. If the THEME is definite or pronominalized, an SVC is used to express the state of affairs. Such SVCs typically have a handling verb as first verb and the three-place verb occurs as the final verb in the series. There are no definiteness or pronominalization restrictions on the objects in the SVC (see Stewart

7 The term "Clause Chaining" is unfortunate as it is used in other traditions to talk of a clause combining strategy in which clauses are linked but the verbs in the clauses in the series are marked for dependence. A better tem for these SVCs might be sequential.

8 In some Akan SVCs the subject is marked on each verb. One context in which this happens is when the subject is the first person (see Ameka 2005b) 
1963, Osam 2004). Thus a three-participant situation involving a pronominal THEME can be expressed grammatically with an SVC as in (44).

$$
\begin{aligned}
& \text { o-de sika no ma-a me } \\
& \text { 3SG-TAKE money DEF give-PAST 1SG } \\
& \text { 'S/he gave me the money' }
\end{aligned}
$$

It was already indicated in section 4.1 that some ditransitive verbs do not have the definiteness restriction. It was also indicated that there are different classes of verbs that surface with three arguments in a clause. Verb serialization is thus not the only strategy for coding three-participant situations. As I have argued throughout for these West African serializing languages, SVCs are but one among other devices, primarily three-place predicates and adpositional constructions, for coding three-participant situations.

\section{Summary and concluding remarks}

I have explored the behaviour of three-place verbs, and three-place constructions in three Kwa verb serializing languages of West Africa. One conclusion that emerges is that contrary to the widespread assumption that these languages lack three-place verbs, each of the languages surveyed has a set of these verbs, not just those of the "give" or transfer type but also those involving location as a third participant type. One difference between the languages surveyed is that in the Gbe languages (Ewe, Gen, Aja, Fon, Gungbe) there are two orders for double object constructions- a THEME-GOAL and a GOAL-THEME order. In the other languages, Akan and Likpe, only one type of construction, the GOAL-THEME order type, is found. An important feature of the languages that promotes or is responsible for the pervasive use of constructions in which a verb surfaces with three arguments is the presence of obligatory complement verbs in these languages. Some of these verbs code a third participant in the situation as a direct argument of the verb (cf. Essegbey 1999, 2003, 2010).

While serialization is used in Akan as an option of coding three-participant situations when the THEME is definite (or pronominalized) for a small set of verbs, the relationship between SVCs and three-place verbs or constructions as alternates is not borne out by the rest of the data. In Ewe, for instance, the motivation for the use of SVCs to code three participant situations relates to the semantics of the situation. A semantic difference between an SVC involving transactions and a three-place construction is that the former codes a direct transfer (between the participants) while the latter codes caused transfer. Furthermore, we have shown that one of the differences between a three-place construction and a dative prepositional construction with respect to verbs of communication is that of addressee as recipient for the former, and as addressee as an affected participant for the latter.

Moreover, in each of the languages and for some monovalent and bivalent verbs the threeplace construction licenses the introduction of a third participant. Thus we have given 
examples in which the verb for 'strike' or 'hit' in the languages can be used in three-place constructions. Similarly a 'do/make' verb can occur in three-place constructions. In fact in Ewe, as shown in (45) the verb occurs in various three-place constructions including oblique ones with semantic effects.

a. THEME-GOAL three-place construction

tsi.dza.dza wo náné-m

rain do something-1SG

'The rain did something to me.' (It did something bad to me)

b. DATIVE-OBLIQUE three-place construction

tsi.dza.dza wo náné ná-m

rain do sometthing DAT-1SG

'The rain did something for me.' (It did something good for me)

c. ALLATIVE-OBLIQUE three-place construction

tsi.dza.dza wo náné dé yú-nye
rain do something ALL surface-1SG
'The rain did something against me.'
(It did something that negatively affected me)

The semantic difference between (45a) and (45b) in terms of the double object construction having a malefactive meaning and the dative oblique construction having a benefactive meaning is observed in other West African languages as well. In Akan the benefactive meaning seems to be expressed with a serial dative construction (instead of an oblique construction as in Ewe).

It seems evident that the presence or absence of three-place verbs in verb serializing languages may well be an epiphenomenon. There is no correlation between a serializing language and the presence or absence of three-place predicates and monoverbal three-place constructions such as double object constructions in such a language. It has been indicated that the lack or paucity of clauses that host three arguments in SE Asian serializing languages may be due to their reliance on ellipsis and inferential processes in discourse. For Oceanic languages, Margetts (2007) argues that the lack of ditransitive verbs may be because of their preferred intransitive nature. By contrast, the ubiquity of clauses with three overt arguments in a clause in West African serializing languages, I suggest, may be due to their hypertransitive nature with lots of obligatory complement taking verbs, many of which require a further object to express particular cultural meanings. Thus what may be a predictor of the language type of the West African serializing languages is their possessing a closed class of verbs with no morphological means of creating new verbs. This shifts the burden in the languages to syntactic means of expressing predicate meanings and to various verbal constructions such as 
obligatory complement verb constructions and their interaction with argument structure constructions.

\section{Abbreviations}

$\begin{array}{llll}\text { AGR } & \text { agreement marker } & \text { INFER } & \text { inferential marker } \\ \text { ALL } & \text { allative } & \text { LINK } & \text { linker } \\ \text { AVOD } & \text { adjunct verb object dative } & \text { LOC } & \text { locative } \\ \text { CAUS } & \text { causative } & \text { NEG } & \text { negative } \\ \text { CM } & \text { class marker } & \text { PAST } & \text { past tense } \\ \text { CM.PL } & \text { class marker plural } & \text { POSS } & \text { possessive } \\ \text { COMP } & \text { complementizer } & \text { POT } & \text { potential } \\ \text { DAT } & \text { dative } & \text { PRED } & \text { predication marker } \\ \text { DEF } & \text { definiteness } & \text { QV } & \text { quotative } \\ \text { HAB } & \text { habitual } & \text { RED } & \text { reduplicative } \\ \text { IC } & \text { inherent complement } & 1 & \text { first person } \\ \text { INDEF } & \text { indefiniteness } & 2 & \text { second person } \\ \text { SCR } & \text { subject cross-reference } & 3 & \text { third person } \\ \text { SG } & \text { singular } & & \\ \text { UFP } & \text { utterance final particle } & & \end{array}$

\section{References}

Ameka, Felix K. 1990. The grammatical packaging of experiencers in Ewe: a study in the semantics of syntax. Australian Journal of Linguistics, 10(2).139-181.

Ameka, Felix K. 1996 Body parts in Ewe grammar. In Chappell, Hilary and William McGregor (eds.), The grammar of inalienability: a typological perspective on body part terms and the part-whole relation, 783-840. Berlin: Mouton.

Ameka, Felix K. 2002a. The cultural scripting of body parts for emotions: On jealousy and related terms in Ewe. Pragmatics and Cognition, 10(1/2). $21-45$.

Ameka, Felix K. 2002b. The progressive aspect in Likpe: Implications for aspect and word order in Kwa. In Felix K. Ameka and E. Kweku Osam (eds.), New directions in Ghanaian Linguistics, 85-111. Accra: Black Mask.

Ameka, Felix K. 2005a. Forms of secondary predication in serializing languages: depictives in Ewe. In Himmelmann, Nikolaus P. and Eva Schultze-Berndt (eds.), Secondary 
predication and adverbial modification: crosslinguistic explorations in the syntax and semantics of depictives, 335-378. Oxford: Oxford University Press.

Ameka, Felix K. 2005b. Multiverb constructions on the West African littoral: microvariation and areal typology. In M. Vulchanova and T. A. Åfarli (eds.), Grammar and beyond: Essays in honour of Lars Hellan, 15-42. Oslo: Novus Press.

Ameka, Felix K. 2006a. Real descriptions: reflections on native speaker and non-native speaker descriptions of a language. In Ameka, Felix K. Alan Dench and Nicholas Evans (eds.), Catching language: the art and craft of grammar writing, 70-112. Berlin: Mouton. Ameka, Felix K. 2006b. Grammars in contact in the Volta Basin (West Africa): On contact induced grammatical change in Likpe. In Alexandra Y. Aikhenvald and Robert M. W. Dixon (eds.), Grammars in contact: a cross-linguistic typology, 114-142. Oxford: Oxford University Press.

Ameka, Felix K. 2006c. Ewe serial verb constructions in their grammatical context. In Alexandra Y. Aikhenvald and Robert M. W. Dixon (eds.), Serial verb constructions: a crosslinguistic typology, 124-143. Oxford: Oxford University Press.

Ameka, Felix K. 2008a. Aspect and modality in Ewe: a survey. In Ameka Felix K. and M. E. Kropp Dakubu (eds.), Aspect and modality in Kwa languages, 135-194. Amsterdam: John Benjamins.

Ameka, Felix K. 2008b. "He died old, dying to be dead right": Transitivity and semantic shifts of DIE in Ewe. In Bowerman, Melissa and Penelope Brown (eds). Crosslinguistic perspectives on argument structure: Implications for learnability, 231-253. Lawrence Erlbaum.

Ameka Felix K. 2009a. Likpe. In Dimmendaal, Gerrit J. (ed.), Coding participant marking construction types in twelve African languages, 239-280. Amsterdam: John Benjamins.

Ameka, Felix K. 2009b. Verb extensions in Likpe (Sekpelé). Journal of West African Languages, 36(1-2). 139-157.

Ameka, Felix K, \& Eva Schultze-Berndt 2000. Adverbialiser or predicate(ion) marker? Ewe $\mathrm{i}$ and its relatives in a typological perspective. Third World Congress of African Linguistics (WOCAL3), Université du Benin, Lome, Togo, 2000.

Amuzu, Evershed K. 1993. Three place predicates in Ewe. MA thesis, University of Ghana, Legon

Avolonto, Aimé. 1995. Pour une approche minimaliste des verbes à objets inhérents en fongbe. PhD thesis. Université du Québec.

Ayeke, Kodzo. 1996. Hlšbiabia [Taking revenge.] Accra: Bureau of Ghana Languages Baker, Mark. 1989. Object sharing in serial verb constructions. Linguistic Inquiry 20.513-553. Bobuafor, Mercy. 2001. Verbal alternations in Ewe. MPhil thesis. University of Ghana, Legon.

Bobuafor, Mercy. 2013. A grammar of Tafi. PhD thesis, Leiden University. LOT Dissertation Series. Utrecht: LOT. 
Bobuafor, Mercy, E. Kweku Osam and Paul Agbedor. 2006/07. Some verbal alternations in Ewe. Afrika und Übersee 89.109-126.

Bril, Isabelle \& Françoise Ozanne-Rivierre (eds.). 2004. Complex predicates in Oceanic languages: Studies in the dynamics of binding and boundness. Berlin: Mouton.

Bruyn, Adrienne, Pieter Muysken, and Maaike Verrips. 1999. Double object constructions in the Creole languages: development and acquisition. In Michel DeGraff (ed.), Language creation and language change, 329-373. Cambridge, Mass: MIT Press.

Christaller, J. G. 1875. A grammar of the Fante and Twi language called Tshi (Chwee, Twi) based on the Akuapem language. Basel

Collins, Chris 1993. Topics in Ewe syntax. PhD thesis, Cambridge, MA: MIT.

Collins, Chris. 1997. Argument sharing in serial verb constructions. Linguistic Inquiry 28(3). 461-497.

Crowley, Terry 2002. Serial verbs in Oceanic: a descriptive typology. Oxford: Oxford University Press.

Déchaine, Rose-Marie 1993. Serial verb constructions. In Jacobs, Joachim, Armin van Stechow, Wolfgang Stenefeld \& Theo Vennemann (eds.), Syntax: an international handbook of contemporary research, 799-828. Berlin: Walter de Gruyter.

Delplanque, Alain. 1998. Le mythe des "séries verbales". Faits de langues 6(11). 231-250.

Diller, Anthony V. N. 2006. Thai serial verbs: cohesion and culture. In Alexandra Y. Aikhenvald \& Robert M. W. Dixon (eds.), Serial verb constructions: a cross-linguistic typology, 160-177. Oxford: Oxford University Press.

Dimmendaal, Gerrit J. 2001. Areal diffusion and genetic inheritance: an African perspective. In Robert M. W. Dixon \& Alexandra Y. Aikhenvald (eds.), Areal diffusion and genetic inheritance: problems in comparative linguistics, 358-392. Oxford: Oxford University Press.

Dorvlo, Kofi. 2008. A grammar of Logba (Ikpana). PhD thesis Leiden University. LOT Dissertation Series. Utrecht: LOT

Enfield, N. J. 2007. Encoding three-participant events in the Lao clause. Linguistics 45(3). 509-538. doi:10.1515/LING.2007.016.

Essegbey, James. 1999. Inherent complement verbs revisited: towards an understanding of argument structure in Ewe. (MPI Dissertation Series) $\mathrm{PhD}$ dissertation. Leiden University.

Essegbey, James. 2003. On definiteness asymmetry in double object constructions. In Lebikaza, Kezie (ed.), Proceedings of the $3^{\text {rd }}$ World Congress of African Linguistics, $127-$ 141. Cologne: Rüdiger Köppe,

Essegbey, James. 2010. Inherent complement verbs and the basic double object construction in Gbe. In Aboh, Enoch O. \& James Essegbey (eds.), Topics in Kwa syntax, 117-194. Dordrecht: Springer.

Evans, Nicholas. 2003. A Pan-dialectal grammar of Bininj Gun-Wok (Arnhem Land): Mayali, Kunwinjku and Kune. Canberra: Pacific Linguistics 
George, Madugu Isaac. 1975/1981.A grammar of Kwa-type verb serialization: Its nature and significance in current generative theory. PhD Dissertation, UCLA. Ann Arbor: UMI 1981.

Heine, Bernd, Ulrike Claudi, \& Friederike Hünnemeyer. 1991. Grammaticalization: a conceptual framework. Chicago: The University of Chicago Press.

Hellan, Lars. 1988. The phrasal nature of double object clusters. Working Papers in Scandinavian Syntax 42. 3-24.

König, Christa and Bernd Heine. 2007. Are there ditransitive verbs in !Xun? Paper presented at a conference at the Max Planck Institute for Evolutionary Anthropology, Leipzig.

Kropp Dakubu, M. E. 2010. Ga verbs and their constructions. Legon: Institute of African Studies, University of Ghana.

Kwamuar, Sebastian. 1997. Ewo moya na Togbui Agokoli [It surprised Chief Agokoli]. Accra: Bureau of Ghana Languages.

Levin, Beth and Malka Rappaport Hovav. 2005. Argument realization. Cambridge: Cambridge University Press

Lord, Carol. 1993. Historical change in serial verb constructions. Amsterdam: John Benjamins.

Margetts, Anna 2007. Three-participant events in Oceanic languages. Oceanic Linguistics 46(1).71-127

Margetts, Anna and Peter Austin. 2007. Three-participant events in the languages of the world: towards a crosslinguistic typology. Linguistics 45(3). 393-451.

Newmeyer, Frederick. 2004. Some thoughts on the serial verb construction. Atelier du 9 décembre 2004, EHESS, Paris: La notion de "construction verbale en série" est-elle opératoire? Fédération TUL.

Nylander, Dudley K. 1997. Some myths about serial verbs. South African Journal of African Languages 17(3). 85-88.

Osam, E. Kweku. 1994. Aspects of Akan grammar: a functional perspective. $\mathrm{PhD}$ thesis. University of Oregon, Eugene.

Osam, E. Kweku. 1996. The object relation in Akan. Afrika und Übersee 79:57-83.

Osam, E. Kweku. 1997. Serial verbs and grammatical relations in Akan. In Givón, Talmy (ed.), Grammatical relations: a functionalist perspective, 253-279. Amsterdam: John Benjamins.

Osam, E. Kweku. 2004. The Trondheim Lectures: an introduction to the structure of Akan-Its verbal and multiverbal system. Legon: Department of Linguistics, University of Ghana.

Saah, Kofi K., and Ejike Eze. 1997. Double objects in Akan and Igbo. In Déchaine, RoseMarie \& Victor Manfredi (eds.), Object positions in Benue-Kwa, 139-151. The Hague: Holland Academic Graphics.

Stewart, John M. 1963. Some restrictions on objects in Twi. Journal of African Languages 2(2):145-149. 
Felix K. Ameka

Leiden University

f.k.ameka@hum.leidenuniv.nl
Received: 10 February 2012

Accepted: 5 August 2012

Revisions: 23 October 2013 